
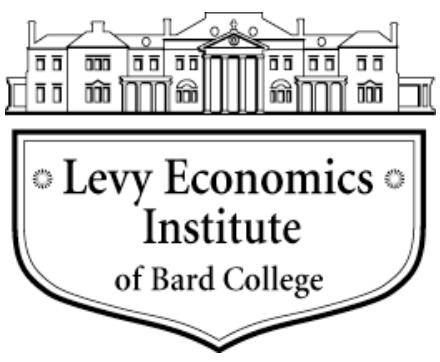

Working Paper No. 761

\title{
Currency Concerns under Uncertainty: The Case of China
}

by

\author{
Sunanda Sen \\ Levy Economics Institute of Bard College
}

March 2013

The Levy Economics Institute Working Paper Collection presents research in progress by Levy Institute scholars and conference participants. The purpose of the series is to disseminate ideas to and elicit comments from academics and professionals.

Levy Economics Institute of Bard College, founded in 1986, is a nonprofit, nonpartisan, independently funded research organization devoted to public service. Through scholarship and economic research it generates viable, effective public policy responses to important economic problems that profoundly affect the quality of life in the United States and abroad.

\author{
Levy Economics Institute \\ P.O. Box 5000 \\ Annandale-on-Hudson, NY 12504-5000 \\ http://www.levyinstitute.org
}

Copyright (C Levy Economics Institute 2013 All rights reserved

ISSN 1547-366X 


\begin{abstract}
The recent declines in China's financial account balance ended the "twin surplus" era and led to a modest decline in the stock of official reserves, which reflects a reversal in expectations for the Chinese currency. Negative balances, which have been visible in China's financial balances since the last quarter of 2011, have heightened fears/anxiety in markets. These deficits stand in sharp contrast to the typical financial account surplus that existed until 2010. The announcement in September 2011 by Chinese monetary authorities of a "two-way floating" RMB in the foreign exchange market has unsettled market expectations and has led to a sharp fall in the financial balance. The latter brought a change in the expectations regarding the RMB-USD exchange rate. This change was reflected in the drop in foreign exchange assets, which was caused by a jump in short-term trade credits to prepay (for imports) in dollars, a rise in dollar advances from banks, and a withdrawal of dollar deposits. These changes have, of late, been a cause of concern relating to the future of China's economic relations vis-à-vis trading and financial partners, which include the United States.

The experience of China, in a changing world beset with deregulation and with speculation affecting her external balance in recent years, provides further confirmation of John Maynard Keynes's observation, in 1937, regarding uncertainty in markets: "About these matters there is no scientific basis on which to form any calculable probability whatever. We simply do not know."
\end{abstract}

Keywords: China; Financial Balances; Official Reserves; Twin Surpluses; Rebalancing; Expectations; Internationalization; Managed Exchange Rate

JEL Classifications: E31, E52, F42, O16, O53 
China's external balance and the future of the Renminbi (RMB) have been the subject of growing concern in recent months. Negative balances, which have been visible in China's financial balances since the last quarter of 2011, have heightened fears/anxiety in markets. The negative sums/numbers were USD -3.02 billion in 2012Q2 and USD -4.21 billion in 2012Q3. These deficits stand in sharp contrast to the typical financial account surplus, which have been as high as 13.20 billion in 2010Q4. These deficits led to a downward slide in China's official reserves. China's official reserves fell by USD 6 trillion between March and June of 2012. ${ }^{1}$ Negative financial balances and reductions in official reserves put pressure on the RMB and led to depreciation against the USD of 6.30 to 6.41 between April and August of 2012. However, the RMB recovered and appreciated from 6.38 to 6.31 between July 24, 2012 and January 18, $2013 .^{2}$

The twin surpluses in China's external payments, especially in relation to trade, which went hand-in-hand with exchange rate appreciation of the RMB, are important background for the present discussion. The RMB is considered by many to be undervalued and thus responsible for China's trade surpluses. ${ }^{3}$ Some have argued that the remedy involves rebalancing the Chinese economy, which would involve upward adjustments in the exchange rate.

Recently, new concerns have been raised in relation to financial balance deficits in China's external payments and an observed tendency for China's official reserves to fall. In addition, the announcement in September 2011 of a "two-way floating" RMB in the foreign exchange market has unsettled market expectations. We take up these changes as they pertain to further reversals in China's flow of external payments.

This paper also examines the factors that create changes in China's financial balance. We argue that these changes are explained by changes in the level of expectations. Some of the factors cited above relate to current arguments for an internationalization of the RMB; some of these proposals have been modified in light of current developments in China's balance of payments.

\footnotetext{
${ }^{1}$ State Administration of Foreign Exchange, http://www.safe.gov.cn/wps/portal/english/Home

${ }^{2}$ XE Currency Charts, http://www.xe.com/currencycharts/

${ }^{3}$ See, for example, Paul Krugman, "Taking On China," The New York Times, September 20, 2010. http://www.nytimes.com/2010/10/01/opinion/01 krugman.html?_r=2\&partner=rssnyt\&emc=rss\&
} 


\section{TWIN SURPLUSES AND THE MANAGED EXCHANGE RATE OF THE RMB}

It is widely recognized that integration with the global markets has been matched by a twin surplus in China's balance of payments and spectacular increases in its trade surplus and net capital inflows. Trade was briefly interrupted with modest declines in exports during the global economic crisis of 2008-09. ${ }^{4}$ China's trade balance, taken within the context of US current account deficits, has been characterized by many observers as a major source of global payments imbalances. China's trade surplus, according to US monetary authorities, is related to the undervaluation of the RMB, which is managed by Chinese monetary authorities in the foreign exchange market.

Payment imbalances among major economies such as the US and China have been cited as a potential cause of global financial upheavals that, as of late, have become rather systemic. Policy proposals to restore balance to the external accounts of countries with trade surpluses often include deflationary strategies and a revaluation of the national currency, as with the "rebalancing" package US monetary authorities have recommended to China. Ben Bernanke, US Fed Chairman, has argued that the US is a "passive" partner, adjusting to the "savings glut" of East Asian economies (including China) and their purchase of US Treasury Bills denominated in dollars (Bernanke 2005). ${ }^{5}$ According to such arguments, the US's current account deficit is a consequence of the "savings glut" in China and other East Asian countries.

The counter argument is that China, as a result of holding large stocks of US Treasury bills, has become trapped in the machinations and uncertainties associated with the exchange rate between the US dollar and the RMB. ${ }^{6}$ Incidentally, speculation is rampant in the Chinese economy despite a recent clampdown on the housing/real estate markets and on the underground credit network. ${ }^{7}$ It has also been argued that the US must rebalance its own economy by keeping consumption growth below GDP growth while strengthening its international competitiveness.

\footnotetext{
${ }^{4}$ IMF Data warehouse, http://elibrary-data.imf.org/DataReport.aspx?c=1449311\&d=33060\&e=161868

${ }^{5}$ For a position along these lines at a think tank in the US, see Dunaway (2009).

6 “China Must Avoid Lending to 'Troubled' Euro-Asia Nations, Yu Yongding Says," Bloomberg News, September 13, 2011. http://www.bloomberg.com/news/2011-09-14/china-must-avoid-loans-to-troubled-nationsyongding.html

${ }^{7}$ Yu Yongding, “The Chinese Bear's Feeble Growl," Project Syndicate, November 29, 2011. http://www.projectsyndicate.org/commentary/the-china-bears--feeble-growl
} 
An analysis of the recent deterioration of China's financial account reveals at least four major departures in China's exchange rate management policy, each of which represents a substantial change from China's past currency management practices.

First, in 2005, China announced that it would end the prevailing fixed official RMBUSD rate, largely as a result of pressure from the US. Despite its twin surpluses between the capital and current accounts, China had maintained an exchange rate of approximately 8.27 RMB to the USD since 1997 . The change to a managed floating rate in 2005, still supported by foreign currency purchases (flowing in abundance given the twin surpluses), caused the RMB to rise immediately to $8.11 \mathrm{RMB}$ to the dollar, and has seen gradual appreciation since then. Despite continued appreciation, the change to a floating RMB did not lead to currency fluctuation until the third quarter of 2011. The steady deregulation of China's financial markets, which began in 2005, continued with increasing net capital inflows. The Chinese monetary authorities had to manage the continued inflow of capital resulting from the twin surpluses to prevent appreciation of the RMB. Purchases of foreign currency contributed to an accumulation of official reserves of USD 3.18 trillion by December 2011, dropping from its peak level at USD 3.27 trillion for August 2011. ${ }^{8}$

The second change in China's currency management policy came in 2007 when it became possible to privately hold foreign currency. With the continued appreciation of the $\mathrm{RMB}$, the market value of the RMB was not immediately affected by private holdings of foreign currency. Thus, in the presence of rapid domestic growth and expectations of continued appreciation in the RMB, this policy change did not lead to currency speculation and outflows. ${ }^{9}$ Currency speculation would come later when expectations of a possible depreciation started to build up, in turn signaled by a shift in currency management and downturns in the financial account, which came in the third quarter of 2011.

The third policy departure was implemented in September 2011 — the "advent of RMB's two-way floating process." 10 A moderate drop in China's trade surplus and financial account balance by 2011Q3 led the People's Bank of China to allow a "two-way float" in the foreign exchange market. This ended a long-standing consensus of the unidirectional movement of the RMB that had previously prevailed. In principle, the measure allowed the currency to depreciate

\footnotetext{
8 “China's Foreign Exchange Reserves, 1977-2011," Chinability. http://www.chinability.com/Reserves.htm

${ }^{9}$ China Economics Seminar, blog. http://ineteconomics.org/blog/china-seminar

${ }^{10}$ China Seminar, "China's FX Flow Framework," China Economics Seminar, March 27, 2012. http://ineteconomics.org/blog/china-seminar/china-s-fx-flow-framework
} 
for the first time. ${ }^{11}$ However, "two-way floating" did not automatically reverse the upward movement of the RMB, which continued to appreciate, ${ }^{12}$ though at a slower pace. During the same period, official reserves rose and direct purchases of foreign exchange by the state continued. Reserves by December 2011 stood at USD 3.18 trillion. $^{13}$

The fourth and final change came in April 2012 when China officially widened the daily trading limit of the RMB against the USD from 0.5 percent to 1.0 percent. This measure allowed the RMB to move in both directions and some China experts maintain that is expected to encourage wider use of the RMB in international markets. ${ }^{14}$

As the RMB continued to appreciate despite all of these changes, expectations of depreciation in the currency continued to mount. ${ }^{15}$ This was reflected in the transactions of the country relating to its capital and financial account, which are analyzed below.

US officials continue to express their concern regarding the exchange rate and to see China's exchange rate policy as the cause of continuing global current account imbalances. On April 15, 2010, the US Treasury went so far as to raise the issue of whether or not China should be officially described as a currency manipulator. ${ }^{16}$

In July 2005, increased pressure to adjust the currency upward, especially from the US, led to an official announcement to delink the RMB from the USD. This led to moderate and steady revaluations of the RMB by the market with the exchange rate rising from RMB 8.28 to 8.11 per USD. The movements in the exchange rate were not responsible for currency speculation until the end of 2011, and more so with the prevailing appreciation in the RMB rate.

\section{“TWO-WAY FLOATING” OF THE RMB ANNOUNCED AND REVERSAL IN CAPITAL ACCOUNT FLOWS}

The situation has changed dramatically since then, especially with the announcement of "twoway floating" of the RMB in September 2011. A moderate drop in China's trade surplus and the

\footnotetext{
${ }^{11}$ China Economics Seminar, blog. http://ineteconomics.org/blog/china-seminar

${ }^{12}$ USD to CNY exchange rate for July 5, 2012 (http://www.exchange-rates.org/Rate/USD/CNY/7-5-2012) and USD to CNY exchange rate for January 11, 2013 (http://www.exchange-rates.org/Rate/USD/CNY/1-11-2013)

13 “China's Foreign Exchange Reserves, 1977-2011," Chinability. http://www.chinability.com/Reserves.htm

14 Xia Xiaopeng, Han Lin, and Tang Danlu, "Floating Exchange Rate Promotes Yuan Internationalization," Xinhuanet, April 16, 2012. http://news.xinhuanet.com/english/indepth/2012-04/16/c_131782276.htm

${ }^{15}$ Lu Jianxin and Pete Sweeney, "CHINA MONEY-Yuan Depreciation a Realistic Possibility," Reuters, May 23, 2012. http://www.reuters.com/article/2012/05/23/markets-china-debt-idUSL4E8GG7BT20120523

${ }^{16}$ Wang Yong, "Avoiding a US-China Currency War: Need for Rational Calculation,” East Asia Forum, April 11, 2010. http://www.eastasiaforum.org/2010/04/11/avoiding-a-us-china-currency-war-need-for-rational-calculation/; XE Currency Charts: USD/CNY Chart (http://www.xe.com/currencycharts/?from=USD\&to=CNY\&view=2Y)
} 
financial account balance by 2011Q3 led the People's Bank of China to allow the "two-way float" in the foreign exchange market, thus ending the long-standing consensus of one-way RMB appreciation. In principle, the measure allowed the currency to depreciate for the first time, falling from RMB 6.30 per USD in April 2012 to RMB 6.41 by August 2012. ${ }^{17}$

It bears repeating that the mandatory sale of foreign exchange had been deregulated in August 2007. The measure enabled domestic companies and households to hold foreign currency. ${ }^{18}$ This change implied that USDs, if desired, could flow out from private channels and create capital account deficits. Interestingly, this did not occur until 2011 because of rapid growth in China and appreciation expectations for the RMB continued to prevail in the market. The changes since September 2011 bring us to the question of the expected changes in the exchange rate of the RMB and how it will be managed. These questions become more relevant in the context of unanticipated deficits in China's financial balance in the balance of payments account. $^{19}$

\section{CHANGING PATTERNS OF FINANCIAL BALANCE: SOME DETAILS}

The announcement of "two-way floating" and the potential losses associated with a decline in the value of the RMB have affected China's external payments balance. These changes raise concerns regarding the sustainability of China's external transactions in the global economy. ${ }^{20}$

An examination of official statistics reveals a sharp fall in China's financial account balance since 2011. This is the first time a negative balance has been recorded. 2011Q4 shows a decline of USD -29.0 billion and 2012Q4 shows a decline of USD -4.1 billion. These changes have raised questions as to whether or not there is a capital flight from China. ${ }^{21}$ These changes also raise concerns for the development of the RMB rate for the years ahead.

Between April and August 2012, the RMB actually depreciated, moving from 6.30 to 6.41 per dollar. However, despite these developments, the RMB has continued to appreciate,

\footnotetext{
${ }^{17}$ Chine Seminar, "China's FX Flow Framework," China Economics Seminar, March 27, 2012. http://ineteconomics.org/blog/china-seminar/china-s-fx-flow-framework

${ }^{18}$ He Langsha and Liu Chang, "China Should Keep Sufficient Foreign Exchange Reserves," China Economic Net, October 9, 2011. http://english.peopledaily.com.cn/90780/7612542.html

${ }^{19}$ China Seminar, "Is Capital Flight Taking Place in China?" China Economics Seminar, November $29,2012$. http://ineteconomics.org/blog/china-seminar/capital-flight-taking-place-china

${ }^{20}$ Lu Jianxin and Pete Sweeney, "CHINA MONEY-Yuan Depreciation a Realistic Possibility," Reuters, May 23, 2012. http://www.reuters.com/article/2012/05/23/markets-china-debt-idUSL4E8GG7BT20120523

${ }^{21}$ China Seminar, "Is Capital Flight Taking Place in China?" China Economics Seminar, November $29,2012$. http://ineteconomics.org/blog/china-seminar/capital-flight-taking-place-china
} 
albeit at a slower pace. The rate moved up from RMB 6.38 to RMB 6.31 between July 24, 2012 and January 18, 2013. In effect, the exchange rate of the RMB appreciated by 23.2 percent between November 18, 2005 and November 18, 2011. ${ }^{22}$

An examination of China's balance of payments reveals several important facts. First, there was very little change in the prevailing trend in the trade balance for goods and services, except for a small drop in 2011Q4, which recovered to higher levels by the second and third quarters of 2012. ${ }^{23}$ Second, net investment income, the other item in the current account that consists of a reinvestment of earnings, showed a larger negative net flow of USD 1.93 billion by 2012Q2, largely with incentives to foreign corporates to remit their earnings abroad in foreign currencies and due to prevailing tendencies for a depreciation of the RMB. ${ }^{24}$ Third, notable changes were apparent in China's financial account, with negative balances of USD 3.02 billion and USD 4.21 billion in the second and third quarters of 2012. In contrast to the financial account surpluses of USD 13.20 billion in 2012Q4, the negative financial account is cause for concern and demands explanation. ${ }^{25}$ Taken together, these changes present a new set of concerns and raise the possibility that China's exports will become more competitive than before.

An analysis of the components of the changes in the financial balance reveals:

1) The reversal in the financial account from large surpluses to deficits in more recent periods referenced above cannot be explained by proportionate declines in foreign direct investment inflows, as these fell only marginally between 2010 and 2012.

2) There was rise in net portfolio asset flows, presumably due to prospects of a rising USD vis-à-vis the RMB, and while portfolio investment liabilities increased, they were more than neutralized by the rise in assets.

3) A reversal in "other investments" appeared due to a drop in net short-term trade credits from zero in 2010Q4 to USD -3.3 billion in 2012Q4. This change can be interpreted in terms of the rise in trade credits advanced abroad against China's imports, which was presumably lucrative given the expected rise in the dollar rate for the RMB.

\footnotetext{
22 “Chinese Yuan-US Dollar Exchange Rate Daily,” http://www.futureofuschinatrade.com/fact/chinese-yuan-usdollar-exchange-rate-daily (site discontinued).

${ }^{23}$ The sum was at $\$ 6.87$ billion and $\$ 7.28$ billion, respectively, by Q2 and Q3 of 2012, which was even higher than $\$ 5.54$ billion in Q4 of 2011 (State Administration of Foreign Exchange, http://www.safe.gov.cn/wps/portal/english/Home).

${ }^{24}$ State Administration of Foreign Exchange, http://www.safe.gov.cn/wps/portal/english/Home

${ }^{25}$ State Administration of Foreign Exchange, http://www.safe.gov.cn/wps/portal/english/Home
} 
4) There was an increase in the long- and short-term loans advanced with a negative balance of USD 2.5 billion in 2012Q2.

5) There were changes in "currency and deposits" entries that recorded steep increases in the negative balance of USD -6.39 billion in 2012Q2, largely due to the withdrawal of foreign currency (mostly USDs) from banks with an expected increase in the dollar rate vis-à-vis the RMB.

6) There was an increase in liabilities, led by trade credits advanced abroad against China's imports, which rose from USD -3.1 billion in 2011Q2 to USD 2.70 billion in 2012Q2. Expectations for a depreciating RMB, especially given the announcement of the "twoway floating" of the currency, appear to have prompted domestic agents to collect trade credits in dollars against imports from abroad, thus inflating the sum as above.

7) Finally, there have been changes in China's exchange reserves, which dropped from USD 3.30 trillion in March 2012 to USD 3.24 trillion in June $2012 .^{26}$ This change was reflected in the flow of reserve assets (or foreign exchange), the residual item in the balance of payments, which declined by US 1.12 billion during the second quarter of $2012^{27}$

Over the calendar year 2011, net exports fell short of cross-border receipts/payments balance of foreign exchange by USD 600 billion. This contrasts with the pattern before September 2011 when net receipts of foreign currency were usually larger than net exports. This change can be interpreted as a change in the tendency of traders to advance or delay payments and receipts according to their expectations for the exchange rate of the RMB vis-à-vis the USD. China's net export earnings before September 2011 were subject to delayed payments by importers and advance receipts by exporters in order to gain from the ongoing RMB appreciation. This pattern clearly changed after September 2011 due to greater uncertainty and rising expectations that the RMB might depreciate. Not surprisingly, trade credit accounts showed huge increases during this period, totaling USD 33.2 billion between the first two quarters of 2012, and are expected to be even larger in the third quarter.

There is an observable difference between the cross-border receipt/payment balance and banks' net foreign currency purchases, which measured the net funding of Chinese companies by domestic banks. Prior to October 2011, this difference was usually negative, which indicated

\footnotetext{
${ }^{26}$ State Administration of Foreign Exchange, http://www.safe.gov.cn/wps/portal/english/Home

${ }^{27}$ State Administration of Foreign Exchange, http://www.safe.gov.cn/wps/portal/english/Home
} 
that Chinese companies sold more dollars to banks than they received from international trades. $^{28}$ The data also show that foreign currency loans by banks continued to increase much faster than foreign currency deposits during the past few years.

Prior to September 2011, Chinese importers and exporters, as well as domestic and foreign corporates, were borrowing US dollars from banks and converting them to Renminbi. This long-standing trend was reversed by October 2011. Traders and corporates shorted the RMB, seeking to reduce USD liabilities and increase USD assets. Such moves also contributed to the net outflows in the financial account. Chinese officials stated, "two vital drivers of the capital outflow resulted from ... speculation activities" by traders and corporates. ${ }^{29}$

To repeat, with expected depreciation in the RMB, domestic importers tend to advance payment of USDs, which affects the foreign exchange settlement between importers and banks. In addition, domestic importers receiving dollars from exports are inclined to hold USD assets rather than exchange their USDs for RMBs; this also affects the foreign exchange settlement between exporters and banks. Between the two, there arose a tendency to short the RMB and hold the dollar long. As for foreign corporates, before September 2011, foreign companies with a long-Reminbi bias preferred to receive in Reminbi and pay in USD. By 2011Q4, foreign companies reversed this pattern and tended to pay in Renminbi and receive in USD. As a result, the RMB settlement receipt/payment ratio for banks shifted from 1:2.2 in January-August 2011 to $1.4: 1$ in September-December 2011. The overall ratio was 1:1.3 in 2011 and 1:5.3 in 2010. ${ }^{30}$

These changes affected the supply of liquidity in China's domestic economy. Unlike previous years when inflows of foreign currency were quickly transformed into RMB, the new pattern leads to less liquidity formation. There is a greater tendency to hold dollars in the face of a possible rise in the dollar. In addition, privately held stocks, as officially permitted since 2007 , now work to preempt dollars held by the state and/or their conversions in RMB. On the whole, China's monetary authorities have far less capacity to generate credit. This is a situation that demands our attention given the renewed danger of a global recession originating in Euroland.

\footnotetext{
${ }^{28}$ China Economics Seminar, blog. http://ineteconomics.org/blog/china-seminar

${ }^{29}$ China Seminar, "Is Capital Flight Taking Place in China?" China Economics Seminar, November $29,2012$. http://ineteconomics.org/blog/china-seminar/capital-flight-taking-place-china

30 http://ineteconomics.org/blog/china-seminar/china-s-fx-flow-framework
} 


\section{CONCLUDING OBSERVATIONS}

The recent declines in China's financial account balance ended the "twin surplus" era and led to a modest decline in the stock of official reserves, which reflects a reversal in expectations for the Chinese currency. While gradual increases in the RMB rate, as managed by the monetary authorities, boosted the holding of the RMB until "two-way floating" was announced by the state, the latter brought a change in the expectations regarding the RMB-USD rate in the market. As stated above, this change was reflected in the drop in foreign exchange assets, which was caused by a jump in short-term trade credits to prepay (for imports) in dollars, a rise in dollar advances from banks and a withdrawal of dollar deposits in banks. The result of these changes included a moderate decline in the stock of official reserves.

It is important to focus on the fact that recent changes in China's external account, which include sharp marked deterioration in the balance of the financial account and declines on forex reserves, are mostly due to changes in expectations and with uncertainty in the foreign exchange market regarding the RMB in relation to the USD and other currencies. The preceding analysis of China's external payments in relation to changing expectations reminds us that we need to start from an assumption of uncertainty and not one of perfect information. As formulated by John Maynard Keynes (1936) with the publication of The General Theory of Employment, Interest and Money, the "weight... of events, viewed on a 'subjective' basis, was to determine probability under uncertainty." And in case the "weight" happened to be too small, uncertainty was considered to be irreducible, while probability could not be ascertained. Keynes reiterated this point in 1937 with the statement, "About these matters there is no scientific basis on which to form any calculable probability whatever. We simply do not know" (Keynes 1937).

The experience of China, in a changing world and with speculation affecting her external balance in recent years, provides further confirmation of the message Keynes left many years ago. 


\section{REFERENCES}

Bernanke, B. "The Global Saving Glut and the U.S. Current Account Deficit." Remarks at the Sandridge Lecture, Virginia Association of Economists, Richmond, Virginia, March 10. http://www.federalreserve.gov/boarddocs/speeches/2005/200503102/

Dunaway, S. 2009. Global Imbalances and the Financial Crisis. Special Report No. 44. Washington, DC: Council on Foreign Relations, Center for Geoeconomic Studies.

Keynes, J. M. 1936. The General Theory of Employment, Interest and Money. New York: Harcourt, Brace.

1937. “The General Theory of Employment." Quarterly Journal of Economics 51: 209-23. 